\title{
A TRANSITORY SETTLEMENT ON THE WAY BACK TO VENEZUELA: A TALE OF VULNERABILITY, EXCEPTION, AND MIGRANT RESISTANCE IN TIMES OF COVID-19
}

\author{
Um assentamento transitório no caminho de volta para a Venezuela: \\ uma história de vulnerabilidade, exceção e resistência de migrantes \\ em tempos de Covid-19
}

Mauricio Palma-Gutierrez ${ }^{*}$

\begin{abstract}
Due to the economic and social consequences of the Covid-19 emergency of 2020, many vulnerable Venezuelan migrants scattered across South America decided to return to their country overland. Simultaneously, exceptional measures imposed during the pandemic resulted in increased domestic and international political constraints to their mobility. Different strategies to resist and overcome such restrictions emerged in this scenario. Drawing upon the concept of Temporary Migrant Multiplicities (Tazzioli, 2020), I analyse how to camp became one of those collective strategies. I present the results of a digital ethnography focusing on a transitory settlement built (and later abandoned) by some 500 persons returning to Venezuela, between May and July 2020 in the outskirts of Bogotá (Colombia). I thereby explore how vulnerabilities can turn into vehicles of resistance in contexts of arbitrary control over precarised human mobility, such as Covid-19 exceptional politics.
\end{abstract}

Keywords: Venezuelan migrants; resistance; temporary migrant multiplicities; state of exception; Covid-19; Colombia; digital ethnography.

Resumo. Devido às consequências econômicas e sociais da emergência Covid-19 de 2020, muitos migrantes venezuelanos vulneráveis espalhados pela América do Sul decidiram retornar por terra ao seu país. Simultaneamente, medidas excepcionais impostas durante a pandemia resultaram no aumento das restrições políticas internas e internacionais à sua mobilidade. Nesse cenário, diferentes estratégias para resistir e superar tais restrições surgiram. Com base no conceito de Multiplicidades Migrantes Temporárias (Tazzioli, 2020), analiso como o acampar tornou-se uma dessas estratégias coletivas. Apresento os resultados de uma etnografia digital com foco em um assentamento transitório construído (e depois abandonado) por cerca de 500 pessoas que retornam à

Doctoral Researcher, Department of Politics and International Studies, University of Warwick. Coventry, United Kingdom. E-mail: Mauricio.Palma-Gutierrez@warwick.ac.uk. Orcid: https:// orcid.org/0000-0001-6988-4543. 
Venezuela, entre maio e julho de 2020 nos arredores de Bogotá (Colômbia). Assim, exploro como as vulnerabilidades podem se transformar em veículos de resistência em contextos de controle arbitrário sobre a mobilidade humana precarizada, como no caso das políticas de exceção da Covid-19.

Palavras-chave: migrantes venezuelanos; resistência; multiplicidades migrantes temporárias; estado de exceção; Covid-19; Colômbia; etnografia digital.

\section{Introduction ${ }^{1}$}

Lockdowns and other exceptional measures implemented at the beginning of the Covid-19 outbreak in 2020 implied a major challenge for many of the 3.3 million Venezuelans living across South America at the time (R4V, 2020)2. The vast majority of them had fled political and economic turmoil in their origin country in the years before the pandemic (Páez, Vivas, 2017; Ramos Pismataro, Rodríguez, 2019; Krüger et al. 2020). Lockdown-related economic hardship led to the precarisation of labour across the region. Many already vulnerable migrants lost their jobs, and many others, once unable to afford the rents, were evicted from their accommodations. Hundreds of women, men and children were forced to sleep on the streets of cities across the region (Mazza, 2020). Although Venezuela's economic and political deadlock seemed far from being solved (Cardozo Uzcátegui, Mijares, 2020) and accusations of systematic human rights violations persisted (OHCHR, 2021), tens of thousands of them started to go back to their country from March 2020 on (Bolívar, Rodríguez, 2021).

A large number of migrants decided to return to Venezuela by bus, hitchhiking, or just using their own bodies as vehicles. Sharing a territorial border

1 The author would like to thank the anonymous reviewers that commented on the first draft of this article.

2 Until December 2020 Colombia, Peru and Chile were hosting the largest number of Venezuelans in the region. The list was followed by Ecuador, Brazil, and Argentina (R4V, 2020). Venezuelan migration management in Colombia, and in other South American countries, was initially conceived under the scope of an unprecedented, one-time, transitory matter in a country with an almost inexistent immigration tradition (Ramos Pismataro, Rodríguez, 2019). In fact, governments of the region kept referring to the situation an "emergency" (UNHCR, 2018), something "extraordinary" (World Bank, 2019, p. 100), and as a "matter of national security" (Trujillo, 2019) way before the rise of the virus. The situation was described by the UNHCR as a major crisis "on the scale of Syria" since at least 2018 (Welsh, 2018). A section of the literature highlights that reception policies before the virus reflected South American regimes' relative openness to migrants, to the point of implementing "policies with a superior standard than international practice" (Acosta et al., 2019, p. 3). However, behind this veneer of humanitarianism, some policies were also vehicles for subjectivising migrants politically and fixating strategies of governmental control over them (Ordoñez, Ramírez Arcos, 2019). Additionally, such initial openness did not endure in time. Recent literature addresses the emergence of a "multilevel crisis of governance" (Acosta, Brumat, 2020 , p. 3) of human mobility across South America issued from, among others, the absence of a coordinated response at the local and international levels, differences in governmental-legal approaches, and differing political interests. 
of 2.200 plus kilometres, neighbouring Colombia became a central hub for the more than 140.000 migrants returning overland between March and December 2020 (El Tiempo, 2021, par. 6). Coming from places as far away as Chile or Peru, they defied closed international border-crossings, violence, criminality, hunger, and domestic mobility restrictions along thousands of kilometres (Mazza, 2020). Many more joined from Colombia, a country itself hosting around 1.8 million Venezuelans according to official numbers (Migración Colombia, 2020c) ${ }^{3}$.

The Venezuelan government reacted cynically. It accused returning migrants of being "bioterrorists" (Bolívar, Rodríguez, 2021, p. 10), who had been "deliberately infected with the coronavirus" (Mazza, 2020, p. 3). It thus established a militarily policed mechanism of surveillance at the border, which was quickly matched by the Colombian authorities (CDH UCAB, 2020). In the years before, both governments had developed an irreconcilable rivalry, and the territorial border had been a common location for power demonstrations (Rodríguez, Robayo, 2019). Meanwhile, a part of the domestic media, some authorities, and many Colombian citizens pointed their fingers at the migrants. Would they constitute massive vectors of contagion? Should they be considered criminals with their movement seemingly ignoring the mobility restrictions in place? Was the sovereign authority of the state at stake, once this 'flux' of people was trying to overcome official international border crossings, kept closed in the name of protection from Covid-19?

Yet, thousands of migrants defied the scheme of control and discipline established, which limited their right to mobility. Continuing to move despite governmental instruction, they contested restrictions directly and indirectly. They formed coalitions with migrants and non-migrants, appropriated spaces, and demonstrated in diverse manners (Krüger et al., 2020). These autonomous actions showed that power, perceived as hegemonic and sovereign, is not undefeatable, even in the context of vulnerability and exception. Thus, this article explores some of the tensions arising in this context. I analyse how resistance to mobility limitations served as a means to overcome a complex scheme of surveillance and control over Venezuelan migrants in Colombia, which was exacerbated by Covid-19 exceptional politics. I thereby focus on the emergence of a Temporary Migrant Multiplicity (Tazzioli, 2020), or a momentary coalition formed by diverse sets of individuals on the move with varying and heterogenous interests and expectations.

\footnotetext{
At the time of writing (February 2021), the Colombian government announced its decision to grant Temporary Protection Status to all Venezuelans in the country, for 10 years. Its aim is to regularise about one million undocumented migrants and to extent the residence permit of some 800.000 people that already live in the country under other sorts of temporary permits. According to a preliminary analysis, the politics behind this action should be analysed under a complex setting of domestic and international interests which are not exclusively defined by absolute humanitarianism (Palma-Gutierrez, 2021a).
} 
Specifically, I am interested in how individuals on the move used their bodies as vehicles of struggle and resistance by overcoming their own vulnerabilities (Butler, 2016). I thus approach the actions and reactions of a group of persons going back to Venezuela overland during the Covid-19 emergency. I explore the social setting of an informal settlement, existing between May and July 2020, some migrants established in the outskirts of Bogotá (Colombia), on the main road to the Venezuelan border. There, around 500 Venezuelans provisionally gathered on their way to their origin country. This place was known as a camp by media, officials, and the migrants themselves. Its story unpacks how the Covid-19 exception served for instrumentalising humanitarian reasons in migration management, useful to put in place a largely undemocratic schema of control (Fassin, 2010). Yet, it also shows how this sort of disciplinary scaffoldings can be overcome through collective, autonomous action. To camp, in the example, proved to be a rather effective resistance strategy to arbitrary power mechanisms in place.

In the next section, I present the conceptual framework under which the study was designed. Section three approaches the methodology developed for observing the social interactions in and around the camp, and introduces a digital ethnography carried out because of (or despite) the research limitations in place due to the pandemic. In section four, I focus on the image of the camp, openly promoted by the media, as an intersection of a vulnerable, yet threatening, migrant population. Section five presents the image of exceptionality imprinted on the official actions implemented to govern the camp. Section six focuses on the camp's dwellers, their stories, and struggles. There I unpack the image of resistance embedded in a particular action, to camp, as an essential move to exert resistance, in contrast to the mere analysis of the camp as a place of resistance. Lastly, a conclusion is provided.

\section{Conceptual framework: Vulnerability, Exception, and Resistance}

Vulnerability is a common framework for approaching contemporary crossborder mobility. Much of the traditional literature surrounding the issue identifies it as a leading characteristic in understanding the causes of mass migration (Betts, 2019). Economic and social deprivation, as well as individual and collective political persecution, are widely accepted as conditions experienced to some extent by people on the move. It is commonly acknowledged that these are more vulnerable to hegemonic structures of power than non-migrants (de Haas et al., 2020). Hence, this framework has been influential in defining the agenda of contemporary migration studies, both on the conceptual and normative level. The latter, however, can be a source of disruption and limitation for understanding mobility at work. The sheer analysis of vulnerability has on occasions led to the essentialisation and subjectivisation of migrants and refugees as mere dispossessed beings, suggesting that the conditions derived from their vulnerability limit their 
agency irrevocably. This can lead to the obviation of their own capacity and will to resist power exerted over them.

To overcome this apparent bias, it is useful to recall Butler's analysis of vulnerability and its relationship to resistance. She recalls that "vulnerability is not a subjective disposition. Rather, it characterizes a relation to a field of objects, forces, and passions that impinge on or affect us in some way" (2016, p. 25). In other words, vulnerability is defined by the surrounding and internal conditions of our existence. Yet, it does not necessarily constitute an inherent, immobile feature of life. It is part of us in relation to our being, but not the utter defining part of our existence, and as such, we may deal with it in different ways, even by allowing its mobilisation on our behalf. Following this line, we can mobilise our own vulnerability as an extension of our agency, in contexts of precarity - or the systematised deprivation of bodies as a schema of governmentality fostered by ruling power (Butler, 2006).

Thus, we may focus on resistance as an expression of agency within vulnerability. Butler explains it in two steps:

First you resist, and then you are confronted with your vulnerability either in relation to police power or to those who show up to oppose your political stance. Yet vulnerability emerges earlier, prior to any gathering, and this becomes especially true when people demonstrate to oppose the precarious conditions in which they live. (2016, p. 16)

She thus implies that vulnerability can activate agency amidst precarity:

If we also say that the vulnerability to dispossession, poverty, insecurity, and harm that constitutes a precarious position in the world itself leads to resistance, then it seems we reverse the sequence: we are first vulnerable and then overcome that vulnerability, at least provisionally, through acts of resistance. (2016, p. 16)

Hence, we can question the specific setting resistance is exerted in. In this case, it is necessary to confront resistance to the exceptional times the Covid-19 response emerged in, as part of a specific governmental discipline directed towards mobility. To develop this idea, it is necessary to frame the space of power in place.

Firstly, even if perceived as one of the most generous reception societies in the region (UNHCR, 2021), the Colombian government initially approached migration from Venezuela as an exceptional matter, ever since it began to be perceived as massive during the mid-2010s (Ordoñez, Ramírez Arcos, 2019). Yet, managing migration from Venezuela swiftly became a structural political priority, as the migrants' presence increased in all sections of society. Its management was progressively embedded in a larger international political strategy aimed at undermining the Venezuelan government (Márquez Restrepo, 2019). However, once the pandemic broke out by early 2020, institutions had not fully transited from an emergency response to a humanitarian crisis to long-term reception policies, even if some decisive steps had been taken before. For instance, a law 
against statelessness of new-borns of Venezuelan parents was approved in 2019. Simultaneously the debate leading to the first national law on migration started in the Colombian Congress (Rodríguez, Robayo, 2019). However, in practice, migration management was still mostly subjected to government officials' decisions and presidential executive orders (Krüger et al., 2020). This was related to the absence of structural normative elements, such as a statutory law on international mobility, and the permanent leave to remain for people who had been granted humanitarian permits, among others (Ramos Pismataro, Rodríguez, 2019).

In order to legitimate such a power disbalance, the Colombian authorities have privileged 'generosity' as their leading political technology in migration management (Palma-Gutierrez, 2021b). Under this label, and in absence of statutory norms to regulate migration and human mobility more generally, the government accumulated enough political legitimacy and capacity to be a central, relatively autonomous actor in leading the governmentality of the situation. Such scaffolding is made up today by domestic and international stakeholders, mostly parts of interested governments, political and economic elites, a section of local and transnational bureaucracies, a selection of the civil society concerned, and the academia (Rodríguez, Robayo, 2019). In practice, such situation has made it difficult for critics to address and legitimate their concerns about the signs of absolute power in some of the government's decisions concerning migrants coming from Venezuela (Palma-Gutierrez, 2020). In any event, the Covid-19 crisis implied new exceptional measures directed at all denizens of Colombia, who were subjected to a set of rules defined outside the space of 'ordinary' politics. In practice, this implied for migrants to be subjected to two different strains of exception, which overlapped and could be used by authorities in place, in combination or separately. This echoes Fassin's idea (2010, p. 312) of an "exception within another exception".

Secondly, we may recall the Agambean idea that "the state of exception is not a dictatorship [...] but a space devoid of law, a zone of anomie in which all legal determinations -and above all the very distinction between public and private- are deactivated" (Agamben, 2017, p. 209). In other words, the resistance we are interested in is exerted in a specific temporal-spatial frame. It is located in a grey zone outside either the 'liberal' juridical order through which the Colombian state allegedly organises life (assumed to be that of the rule of law), or a structured, openly autocratic order. In the absence of a juridical-institutional safety net, individuals are thus confronted with the direct exercise of sovereign power.

Thirdly, the exceptions underway resemble the veritable setting of the contemporary world described by Fassin (2010, p. 289): the trivialisation of exceptions justified by an instrumentalised "humanitarian reason". More specifically, migrant resistance in this case is conditioned by the practice of a specific means of sovereign power, arbitrarily defined and justified by the cause 
of protecting life. This scheme was affirmed by differentiating official statistics about the virus, prioritising measures for its control, and equating safety with an instrument for bio-policing, among others. Its emergence reflects humanitarian discourses extending a specific technology of control shaped by ruling entities. Important to note, hegemonic power in place should not be necessarily likened exclusively with state action and authority. It is constructed by complex linkages between dominant actors and structures, from local official elites to economic agents and international bureaucracies, among others, whose specific interactions remain outside the scope of the current analysis.

Individuals on the move also matter in this conceptual setting. It is useful to evoke Mezzadra and Nielson's (2013, p. 15) frame which suggests that these persons are "political subjects, which abide neither the logics of citizenship nor established methods of radical political organization and action, [who] can trace their movements and multiply their powers." In other words, they start the discussion about individuals crossing borders, otherwise essentialised as mere vulnerable subjects, by emphasising their potential as agents of political mobilisation along the specific frames, situations, or contexts they experience - in short, mobilising migrant agency. This is consistent with the claim that "migrations yield moments of autonomy, [such as] moments of uncontrollability and excess, in regard to any attempt to control or regulate them" (Scheel, 2019, p. 4). These moments of autonomy also nourish political resistance.

Focusing on agencies is useful to observe the ways in which individual migrant action may lead to collective association, and thus, to extended forms of resistance. A conceptual understanding that unpacks much of the possibilities in place is that of Temporary Migrant Multiplicities. Tazzioli explains these as:

collective formations [that] do not share an identity but come together in places; in
some cases, they act collectively towards common political goals and they lay claims,
as a result of a shared condition -e.g. being blocked at the border, or not being
allowed to stay in a given place. In this sense they generate unusual forms of political
subjectivity that are, however, often discredited as non-political or criminalised as
unruly mobs. (2020, p. 5)

Drawing upon these ideas, we will focus on analysing the movement and struggle of coalitions of vulnerable individuals identified by the ruling power as part of a policed, homogenous group (Palma-Gutierrez, 2021b). Yet, once more closely observed, we identify a heterogeneous set of individuals with diverse interests and aims, who decide to act collectively. Therefore, group action can emerge as a strategic move to confront shared vulnerabilities derived from the precarity in place. Moreover, when acting in this temporary manner, group members can generate an unusual form of political subjectivity, that might lead to fulfil a specific, time-specific, political aim, such as, in this case, to overcome the restriction to their mobility. 
We may, therefore, explore the extent of this conceptual design through analysing a case of migrant resistance. Beforehand, however, it is necessary to explain the methodological choices made to develop the framework. In the next section I present the basis of the ethnography conducted amid limitations due to the pandemic.

\section{Method: Digital ethnography during the Covid-19 pandemic}

Social research has been disrupted by measures in place for controlling Covid-19. Designing and conducting mobility investigations are no different. Before 2020 literature on migrant resistance and struggles relied heavily on ethnographical accounts and other methods that traditionally involve face to face interaction. Facing a potentially lethal disease, social distancing measures, mobility restrictions within and across national borders and, ethical considerations, among many others, have rendered conducting traditional qualitative research more difficult.

Digitalising ethnographical research has emerged as an alternative. Albeit an idea existing before the Covid-19 outbreak, it has now become increasingly relevant. Building upon "multi-sited ethnography" (Marcus, 1995, p. 97), several authors have adapted the setting of the ethnographic research to the digital realm (Underberg, Zorn, 2013). The idea behind this turn supports the tracing and following of phenomena, people, and power in the digital space, to be a feasible task thanks to the popularity of the internet. Digital ethnographical research today range from participant observations to individual interviews or focus groups.

However, this approach has some limitations. Firstly, it depends on the availability of the observed subjects' access to digital means. In the case of vulnerable individuals on the move, their access is restricted due to economic, infrastructural, political and other factors or a mix thereof. Secondly, much of the data found in these sources is secondary, as it is processed by third parties before becoming available. This is not only the case with texts processed by media outlets or independent bloggers, but also with edited images, audios, and videos. This could imply a major limitation to research (Snelson, 2016).

I hence modified some virtual data-collection procedures and integrated them into an experimental digital ethnography design. I included observations from the internet's 'native' spaces, where primary, non-modified data is likely to be available. These are the social settings developed on the internet, in contrast to the tools imported from the non-digital world into the internet. Examples are social networks, video blogging, meme creation, and beyond. By doing so, I acquired information from the 'bounded' and the 'liquid' spaces integrated online, such as the contextual setting where information is stored, i.e., a post, a conversation, or a blog entry, and the like (Airoldi, 2018). I also considered the 'meta-fields' constituted by the data and information available for a restricted time in, e.g., 
news feeds or thanks to social networks aggregators. These spaces are publicly available sources of raw data which become useful in a restricted setting such as when developing an ethnographic project during the Covid-19 pandemic.

Thereafter, I approached the research topic inductively, by relying on thematic snowballing as the main driver, which would later allow me to define my observation period more precisely, to May-July 2020. I started my search with three key terms defined after a first round of general search ${ }^{4}$. Once the extent of the available information was estimated, I decided to contrast multimedia information found in five different digital settings: (a) Twitter's general search tool, coupled with the selection of three relevant terms for the period May-July $2020^{5}$, (b) Facebook Live videos of the Colombian migration authority during the same period, (c) YouTube reproduction lists of ten local media on the topic ${ }^{6}$, (d) audio reproductions of five local radio stations, and (e) a digital press review built on information published by ten newspapers and magazines ${ }^{7}$. I focused on the information related to migrant life-stories, or the descriptions individuals create building on their lived experiences.

Once core data was identified, I used it to analyse how actors "use symbols and insert communication with meaning" and how these help us to "solve questions that involve extracting meaning from communication" (Hermann, 2008, p. 151-152). I started by organising the data using three different codes ('Vulnerability', 'Exception' and 'Resistance'), defined from the conceptualisation described in section two. This process allowed me to inductively classify defined themes in place associated to one or more of the categories. The purpose was to trace the meanings attributed by individuals and groups of individuals to the events they experience and their actions and reactions in between.

Finally, I organised the findings chronologically, drawing upon Hsieh and Shanon's (2018) approach to contextualisation -or the process of contrasting data with the historical setting in which it was produced. I thus consulted secondary documentary sources. Thereafter, I created a three-section narrative, as a way to

\footnotetext{
${ }_{4}$ "Migrant camp in Northern Highway", "Venezuelan settlement in Northern Highway" and "Hovels in Northern Highway" (Translated from Colombian Spanish: "Campo de migrantes en la Autopista Norte", "Asentamiento de venezolanos en la Autopista Norte" and "Cambuches en la Autopista Norte").

5 "Migrant camp in Bogotá", "Migrants + bus terminal + Bogotá", "Venezuelans + camp + bus terminal + Bogotá" (Translated from Colombian Spanish: "Migrantes + terminal de transportes + Bogotá", "Venezolanos + campo + terminal de transportes + Bogotá").

6 The list included four national TV broadcasters (Noticias Caracol, Noticias RCN, CM\& and Cablenoticias) four national radio broadcasters (Caracol Radio, RCN Radio, Blu Radio and W Radio) and two local TV stations (CityTV and Canal Capital). These were the ten media with the most views according to YouTube statistics to December 2020.

7 I included six international broadcasters (Agence France Press, Deutsche Welle, Reuters, BBC Mundo, France 24 and Voice of America) and four Colombian media outlets (El Espectador, El Tiempo, El Colombiano and La Opinión). These were the ten media with the most online views to December 2020 according to Google News.
} 
organise the main results of the analysis, portraying three different, yet intertwined pictures of the events in and around the informal migrant setting on Bogota's Northern Highway. I present this narrative next.

\section{Picture one: Vulnerability}

Walter Benjamin's idea of the Camp as the contemporary "biopolitical paradigm of the West" (Fassin, 2010, p. 241) has broadly informed the understanding of these spaces as an intersection between hegemonic rule and bodily life. The making of the exceptional conditions that allow the emergence of these human settlements, often hermetic and ruled by bare power, has been revisited and put into question by contemporary philosophers, from Agamben (1998) to Butler (2009) and Arendt (2017[1951]). An extent of research in mobility studies, specifically that concerned with refugee camps and other similar spaces, has been inspired by the latter's reflection:

The human masses sealed off in them [Camps] are treated as if they no longer existed, as if what happened to them were no longer of interest to anybody, as if they were already dead and some evil spirit gone mad were amusing himself by stopping them for a while between life and death before admitting them to eternal peace. (Arendt, 2017[1951], p. 583)

The result is the emergence of a certain kind of epistemology, focusing on observing formal and informal camps and settlements of migrants and refugees as extensions of hegemonic power in place, that limit individuals' aspirations and, even, essences. Yet, literature has also mentioned how these very spaces of abjection may also allow for enabling individual agencies (Scheel, Ratfisch, 2014). Hence, through focusing on migrants' settlements, we can follow the formation of collective aims through the camping process, both limited and enabled by the specific contexts of their emergence.

This is traceable in the example of the informal settlement built by a group of Venezuelans, which came to be in the middle of the partition of one of Bogotás main highways (commonly called the 'Northern Highway') in May 2020. Most of its dwellers had attempted to catch a bus to the Colombian-Venezuelan border (about $550 \mathrm{kms}$ away) at the nearby terminal. However, due to the national lockdown mobility restrictions, many were impeded from travelling. Routes were cancelled or delayed. Ticket prices sky-rocketed and group travel became more difficult. At border crossing points, closed since 2019 amid bilateral political tensions, a precarious humanitarian corridor was negotiated between the two antagonist governments. Yet, "it was not working on a regular basis, [as] Venezuelan [government] arbitrarily defined when and how many people could cross" (Bolívar, Rodríguez, 2021, p. 13).

With no possibility to sleep elsewhere, people decided to camp nearby until finding a solution. They built their tents with cardboard and plastic and tried to stay 
together, even if most of them had not known each other before (Noticias Caracol, 2020a). Citizens, visitors, and authorities transited everyday through the highway that links the Colombian capital to the official crossing points with neighbouring Venezuela. The space became the transitory home of about 500 men, women, and children. Local and international media rapidly became interested in their fate. Most of them perceived the settlement as a node in a larger ongoing issue that affected the South American region, namely the emergence of human caravans of Venezuelans who, due to the economic constrictions caused by the lockdown, returned to their country overland. According to official statistics, some 68.000 persons had returned to Venezuela through the Colombian border by May 2020 (Migración Colombia, 2020c). This number would increase twofold, to 140.000, by the end of the year (El Tiempo, 2021).

The return process seemed to be owed to economic reasoning. Evictions had become commonplace since the start of the first general lockdowns in different reception countries by early and mid-March 2020 (Acosta, Brumat, 2020). This affected many vulnerable sectors of local societies, where the prevalence of labour informality makes it hard to access governmental safety nets. In the case of many Venezuelans living under these conditions, the impact was decisive. Among others, the irregularisation they had been objected to before the pandemic affected them profoundly (Bolívar, Rodríguez, 2021). Amid declining work opportunities and virtually inexistent savings, they were targets of eviction by local landlords, as they were not included in governmental support schemas. In consequence, many decided to return to their country on foot, on paid transportation, by hitchhiking, or a mix of those. They travelled back from places as far away as Chile, Peru, and Ecuador, with many of them having to travel across Colombia in transit to the territorial border with their country (Krüger et al., 2020). In the capital, Bogotá, many others joined their journey. A young woman explained in June 2020:

\footnotetext{
Many of us [Venezuelans] were working [...]. But when the pandemic erupted many of us became jobless. When the quarantine started, many of us were unemployed and our landlords gave us two months of grace, by law. Those who were not able to pay after the two months were evicted... Now, we do not want to stay here any longer. (Caracol Radio, 2020a)
}

For governments in the region, it was problematic to allow migrants unrestricted mobility, as this represented a rupture of the discipline schema designed during lockdown. In fact, it was undesirable, with authorities wanting all denizens to stay at home, even if that implied affecting individuals' chances for achieving a decent livelihood. Moreover, this did not only constitute a domestic issue. International official land-crossing points had been sealed in the name of containing the expansion of the virus (Migración Colombia, 2020b). Yet, mobility across borders continued clandestinely, in great part by resorting to traffickers (Krüger et al., 2020). Governments targeted migrants as threatening their sovereign border authority (CDH UCAB, 2020). Cases of official violence, along the 
Peruvian-Ecuadorian and the Ecuadorian-Colombian borders, against returning Venezuelans were reported on social networks and persecution of returnees was fuelled by official sectors in their origin country (Gozzer, 2020).

Additionally, as mobility continued, suspicions over the migrants' health arose, and the possibility of a specific bio-threat was in the air. Apart from the preoccupation of local authorities that returning migrants might constitute Covid-19 transmission vectors, the position of several Venezuelan government officers was clear in this respect: the returnees were "biological weapons" (Bolívar, Rodríguez, 2021, p. 10). These statements, less explicit in other cases, promoted xenophobia abroad and discrimination within Venezuela. Further, the images of dispossessed migrants, occupying the spaces of roads, parks, public squares, and other venues in many cities also pushed the imagery of these persons as subjects of security concerns. Local claims against the returning Venezuelans as "potential criminals", "rapists", and "gold-diggers" surfaced promptly (Caracol Radio, 2020a).

These elements seem to have informed the picture of vulnerability reported from the camp in Bogotá. On the one hand, victimising narratives were broadly available. As an example, the Agence France Press (AFP), showing a dozen persons around plastic-made tents, described the situation dramatically:

The raining season just started. The improvised tents with cardboard-made soles are wet as they keep attached to the floor. Fear of a Covid-19 outbreak emerges amid increasing overcrowding. [...] There are children, pregnant women, and older adults in the group. There is a stockpiling point for donations from NGOs and particular citizens, but the situation is overwhelming. (AFP, 2020)

On their part, a TV-news anchor started a report in the following way:

In extreme vulnerable conditions but, also, with few bio-security measures, a group of Venezuelans has built a settlement made of hovels in the North of Bogotá. They are demanding the national government to be allowed to travel to their country. (Noticias Caracol, 2020a)

On the other hand, the identification of vulnerability as a threat was also part of the narrative. A thread by members of the audience on Youtube, underneath one of the analysed media reports, exemplifies this:

User: They [Venezuelans] should be deported. They should not be able to return to Colombia and, if they do not like it, well they should keep walking.

Reply 1: The more comfortable we make them feel, the easiest (sic) they will come back [to Colombia]. We should not give them anything [...] Rich Venezuelans should support them; Colombia is a poor country...

Reply 2: There are some studies that state that they just want to go back to Venezuela to seek a haven during the lockdown, [but] when everything gets back to normality, they will come back. In that sense, the cure could be worse than the disease [...] They should take responsibility for their own disgrace... (Caracol Radio, 2020a)

In sum, the settlement was reported to be a place where vulnerable bodies, led by potentially dangerous minds, gathered. Official actions were thus put in 
place. These were shaped by the will to maintain social discipline, and by the implementation of a governmentality schema that justified exceptional actions for managing an exceptional situation. The next section unpacks this process.

\section{Picture two: Exceptionality}

Once media put the spotlight on the settlement, authorities decided to act. The way in which this process took place tells us how they took advantage of the state of exception in place to affirm their control over subjected migrants, and the general public. There were two main official stances regarding the management of the camp. The first was the national government, as the entity commanding general mobility within the rest of Colombia's territory. It oversaw restrictions and permissions to inter-city transport and the management of international borders. The second was the city's Mayor's Office, responsible for the management of the Covid-19 exception within the capital's territory. It is by law in charge of controlling individuals who move within the city and who occupy the city's public spaces. These entities were in a clear competition with each other of winning the general public's approval within the larger picture of Covid-19 management (Torrado, 2020). Yet, in the case of the camp, they tried to convey an image of coordination, necessary for gaining legitimacy with the audiences.

For the national government, it was substantial to explain to the general public that, firstly, the situation was caused by the Venezuelan government, itself a political contender of long standing. Secondly, it was necessary to be identified as the leader in the management of the situation, over local authorities. For instance, the director of the national migration authority stated that:

The return of Venezuelan citizens to their country depends on Venezuela's own capacity to receive them. Daily, only 300 persons can cross [the border]. Venezuelan citizens, who are voluntarily willing to return to Venezuela, must arrange their displacement with the Mayor's Office of the city they are currently at, as we have instructed. (Migración Colombia, 2020b, emphasis added)

Days later, during a Facebook Live event, he said that:

Recently, Venezuelan authorities restricted the entry for Venezuelan nationals to that country. This situation has made us authorise the crossing of only 80 persons a day. In consequence, we had to suspend buses' mobility, which we had coordinated before with the local authorities, until the Venezuelans that are currently at the border voluntarily leave our country. We will gradually re-install this process, always granting human rights, but also recalling the need to grant the right to health and to life of migrants, and that of fellow Colombians. (Migración Colombia, 2020a, emphasis added)

Evidently, these declarations show a will to justify the exceptional measures in place as answers to the actions of the Venezuelan government. Once we look more closely, however, this appears to be part of a larger discursive effort on the part of the Colombian government against its Venezuelan nemesis started 
before the pandemic. In any case, the move seems to be related to a rhetoric that identifies a specific foreign threat as an essential national security concern, something that has been driving the current administration's foreign policy (García Pinzón, Mantilla, 2020).

Yet, these declarations also expose how Fassin's humanitarian reason is used as an instrument for exerting disciplining power over locals and migrants. 'Voluntary' mobility as part of a larger setting of the 'human rights' schema presented are both key elements. The rhetorical effort implies that claiming those rights is only legitimate if their enactment is balanced in light of the impact on the 'health' of the 'fellow' Colombians. In this sense, it is implied that their lives prevail over the migrants'. Therefore, a hierarchy of life is put in place in an arbitrary way, justified by the exception it was conceived in.

The communication strategy by local authorities differed slightly. However, it also aimed at optimising the setting of control and discipline embedded in the exception. For instance, when questioned about the camp, Bogotá's Secretary of Government, part of the Mayor's Cabinet, declared on national TV that:

We [Bogotá's government] are deeply worried about this situation with this Venezuelan community. We have been working with them for some days now in our district, with International Organisations, with the national migration authority, offering them different alternatives. Yet, the only choice we cannot offer them is that of opening the border. This does not depend on us. (Noticias RCN, 2020, emphasis added)

We can sense the use of 'Venezuelan community' as a reference to a subjected population whose control is difficult and in need of disciplinary action -an 'unruly mob' (Tazzioli, 2020). This became clear when he recalled that:

We [Bogotá's government] have offered them alternatives for lodging... there are health squads in place, yet we had problems with some of them, they have not accepted to get tested [for Covid-19] [...] We are especially worried about families with children, yet they insist that they want to keep moving until they get to Venezuela [...] Our invitation for them is not to return to their country. We know the situation in Venezuela is not the best. That is why we have offered them these choices [...] but if we allow the buses to travel from Bogotá, the easiest of all choices, we are just going to have them be repressed in Cúcuta [at the border]. (Noticias RCN, 2020, emphasis added)

The officer's discourse reiterated the border-crossing limitations, but these were not the essential underpinnings of his rhetoric. His appeal was focused on the authority his office was legitimately exerting, by taking charge of the lives of vulnerable subjects in the camp, namely dispossessed migrants, and their families. He emphasised that the officials were having a difficult time, as the choices they were confronted with, due to migrants' behaviour, were putting lives at risk. The official also seems to belittle the situation of people on the move in general, by depicting returning to Venezuela as an easy choice. This rhetorical element reveals a politicised understanding of humanitarian action. In the same line, the city's Mayor stated in an official event days later that: 
We [Bogotá's government] have offered them, in the last month, everything. Paying their rent fees... hotel lodging... care services... We told them, 'you are some 350 people... This is an epidemiological risk'. We offered all of them Covid tests, because, if they are going to stay there, we must know at least they are ok [...] None of them accepted [...] They do not move, as a way of exerting pressure on us and on their government [...] Bogotá will not act irresponsibly by sending people to the border in buses [...] They are there [at the settlement] at their own will [...] We cannot allow them to risk their own life and that of other persons by crossing Colombia. (Alcaldía de Bogotá, 2020, emphasis added)

This declaration unpacks the extent of power during exceptional times. Legitimate hegemonic action is to be exerted through providing what is necessary to maintain life a biological fact. This is exemplified in this case by offering lodgement, paying the fees, or supplying food and essentials, even if doing so implies a direct epidemiological threat. This, however, does not necessarily entail granting the conditions that allow for the full development of social life, which enacts humanity. In this case this is demonstrated by the migrants' will to reach their origin country. This reflection reminds us of the notion of 'bare life' (Agamben, 1998). In the end, the schema of governmentality was intended to justify actions over the camp's dwellers, subjects of control without full rights in the middle of the exception. Paradoxically, they were made responsible for their own vulnerability, as can be inferred from the Mayor's understanding that people who remained in the camp were exerting their free will, as if there existed a broader set of options intrinsically. Her words revealed one instance of humanitarianism being served as a coating for the schema of ruling power in place.

\section{Picture three: Resistance}

At some point in July 2020 different media began to report on the end of the settlement. Migrants had been able to reach the border progressively, by taking bus turns, agreed and organised with the authorities' auspice. The tents were destroyed, and several journalists were quick to emphasise the successful actions undertaken by national and local authorities to minimise epidemiological risks for Colombian citizens (Caracol Radio, 2020b). By the end of the month, the Mayor's Office posted a tweet, in tone of victory:

The last group of the 700 Venezuelans that were camping on the Northern Highway travelled to their country today. The District [of Bogotá] provided healthcare, Covid tests, food and shelter for those who accepted it. (Secretaría de Gobierno, 2020)

However, this politically motivated message ignores the story of the camp's dwellers. Their agency always was at stake during the weeks the settlement stood. This is not to deny that they were presented as both vulnerable and potentially dangerous by the media. Nor that they turned into special subjects of control in the middle of the pandemic, as officers in charge identified an opportunity for their political instrumentalisation. Yet, to camp, in the place and manner they did, was a way of overcoming many of their own vulnerabilities. It was the main 
action that reflected the emergence and enhancement of resistance. They were thereby able to make political statements, using their own bodies and the material elements available. Besides building the camp with their own hands, they also made the space of the settlement their own while making it visible, by exposing their bodies to the cameras and to the general public. They refused to move to other locations or to give up their own sovereignty, as witnessed in their refusal to get tested for Covid-19. Resisting was indeed part of reaching a solution, which was achieved when they were able to move to the border.

One major part of this story was the activation of a transitory coalition of individuals on the move sharing a similar interest - in short, a temporary migrant multiplicity. Persons of different ages, professions, documented and undocumented, with different material means and interests, sometimes colliding, coincided in the camp. One of them was a young man, who had recently lost his job of three years in Colombia. When asked by a journalist, he expressed:

Here, without a job, I cannot live. But there [in Venezuela], I have my own house, my family, my motorcycle... I can live there stress-free. Here you are always under tension, because you must pay the bills, the food... (Noticentro 1, 2020, emphasis added)

This case does not necessarily represent the reality of a major part of Venezuelan migrants, who have left their country after losing their possessions and experiencing the consequences of a complex humanitarian situation (Páez, Vivas, 2017; Bolívar, Rodríguez, 2019, 2021; Krüger et al., 2020). However, it shows the heterogeneity of the social and economic conditions of the camp's dwellers. The young man had settled in a tent near that of a public accountant who had been trying to reach Ecuador before the start of the Pandemic. She, however, had also lost her job once the lockdown started. They both shared this space with persons who had been abroad when the pandemic began. One of them was a young professional, stating that:

The only reason I came here [to Colombia] was to buy some medical materials for my personal use, so that I can practice my craft in my country. I just want to go back... (El Tiempo, 2020)

A man appearing to be in his fifties was also part of the settlement. He said that he kept a "positive mind to rebuild his country" (El Tiempo, 2020) as he was arriving at home soon. Over time, spontaneous leaderships emerged, traceable in the words of another middle-aged man:

Along with my Venezuelan brothers [and sisters], I called this place the 'Return to Venezuela' Camp [...] We are working with several NGOs in order to achieve our transport to the border, with all our Venezuelan brothers [and sisters]. We are looking for 50 buses [...] Our destination is San Antonio del Táchira [in Venezuela]. (El Espectador, 2020) 
As this statement confirms, migrants were able to work with groups of non-migrants, seeking the achievement of their mobility goal. Yet, relations were not always smooth between the camp's dwellers. Far from being inhabited by a homogeneous group, the space was sectorised between individuals who had the material means to buy a ticket and provide food for themselves, and those that did not. These ruptures were evidenced by a young man interviewed by a local TV station:

That division emerged. We talked to the leader of the other side, so that we could work jointly, you know what I mean? So that we could unify our goals, so that we avoid that division between ourselves as Venezuelans... (Arriba Bogotá CityTV, 2020)

The coalition seemed to be important when authorities hardened their measures. This was evidenced by some leaders exposing the tensions that emerged with some officers. During a Facebook Live event organised by a local radio station, a young woman expressed that:

We have been displaced [...] Some days ago the Police and people from the Mayor's Office came by and suggested that we should keep walking [to the border], without offering us a tangible solution. [...] The only thing we demand is that they sell us our tickets. We are experiencing unsanitary situations [...] We do not even have a toilet... (Caracol Radio, 2020a)

She elaborated further, with a stronger tone:

The only thing they [the authorities] want from all of this, is that we vacate this zone. They say this is a green [public] zone, but we cannot keep on walking anymore. There are a lot of children, handicapped people. Look [pointing at an older woman] she is handicapped, she has problems in her back and just one kidney! (Caracol Radio, 2020a)

A couple of days later an exiled Venezuelan parliamentary deputy in Colombia claimed that the camp was 'infiltrated' by Venezuelan government's secret service. Allegedly, its members were paid by Nicolás Maduro's regime to disturb the public order (Sulbarán, 2020). The declarations fuelled suspicions of the migrants' participation in criminal activities further. Yet, this did not impede more embodied examples of resistance to take place. One journalist asked one of the camp's self-proclaimed leaders about their rejection of the local authorities' offer for temporal lodging at a nearby hostel. He replied:

A group left to a shelter, as offered [by the Mayor's Office], so that they can stay there for ten days. My question in this regard is: After those ten days, what [will happen]? We have no certainty of what they are suggesting... They are taking children and women with them. We did not accept, because, after those ten days, what? (El Espectador, 2020)

Another latent struggle emerged over the Mayor's Office's Covid-19 test initiative in the camp. The majority refused to get tested, arguing with a lack of trust in the office's program. As a man explained to a journalist on national TV: 
The Mayor's Office does not give us any guarantee of the legality of these tests. We want an audit from the Red Cross, that confirms that the tests are completely legal. (Noticias Caracol, 2020b)

This autonomous decision resulted in being a major asset for negotiating their mobility. Local authorities were summoned by the media. The situation was implicitly seen as a failure officers were accountable for. Many were placed under public scrutiny for their inability to find a prompt solution (Noticias RCN, 2020). Simultaneously, the general public grew more anxious about the situation. A YouTube feed following a National Newspaper video-post on the situation reflects this:

El Tiempo (User): Venezuelan migrants resist amidst the Pandemic

Reply 1: Out of my country!

Reply 2: To resist? Please! This is out of control!

Reply 3: Go back and resist in your own country

Reply 4: We should push away those who stay... and those who are already leaving, are they going to fight back? Or are they just going to eat all the s\#*@!t they created? (El Tiempo, 2020)

The video that elicited these comments showed a captivating image. It embodied the resistance to the exceptional measures exerted by the ruling power over a vulnerable migrant multiplicity. About fifty persons posed for the camera. It did not matter if they were old or young, if they had the means to purchase a ticket or not, or whether they had come from Chile, Peru, or a nearby place in Bogotá. What mattered in the end was their will to stay where they were until they found a plausible way to move to the border. Meanwhile, they made the space their own by using their humanity. With their heads up, they all sang the Venezuelan national anthem loudly for the cameras: "iAbajo cadenas! gritaba el Señor, y el pobre en su choza libertad pidió" ${ }^{\prime}$. Some weeks later, most of them arrived at the border, as had been their wish.

\section{Conclusion: To camp, and not just $a$ camp}

Vulnerable migrants resist hegemonic schemes of control and discipline, even in the middle of political exceptions, confirming that individual agency and autonomy can be a constant in conditions of utter precariousness. Conceptually, Butler's impression of vulnerability and resistance informs the analysis and extent of political action led by temporary migrant multiplicities, as witnessed through the case of Bogota's Northern Highway settlement. Taking distance from essentialised approaches, that focus on how structures of power in place shape the fate of utterly vulnerable subjects, this text reflected on how this settlement should be analysed beyond the idea of a sheer space for bare life, through dissecting some of the life stories of its dwellers. Negotiation of collective action,

8 "Down with chains!" shouted the Lord; And the poor man in his hovel for freedom implored (El Tiempo, 2020). 
analysed through the lenses of Temporary Migrant Multiplicities, emerges as a central point in the analysis.

At a first glance, the settlement seemed to be a place where a sealed off mass of migrants was left to their own devices in the middle of the pandemic. The economic hardship and the governmental rule in place seemed to be definitive vectors for individual behaviour. Yet, after looking more closely, we realised that within the camp, the actions of building, maintaining, and inhabiting the settlement -in short, to camp- became a strategy for mobilising agency. The collective use of migrant bodies was substantial in this task. Making their claims visible, retaining the sovereign control of themselves and, in the end, persevering in resistance, were all defining elements in the continuation of their quest to reach the Venezuelan territorial border. Many other struggles, some of them also dramatic, were all part of the same ongoing journey and remain unexplored. Yet, the experience of these persons camping in Bogotá shows that resistance to hegemonic power is ever present, and that vulnerabilities can turn into instruments to overcome it.

\section{References}

ACOSTA, Diego; BLOUIN, Cecile; FREIER, Luisa Feline. La emigración venezolana. Respuestas latinoamericanas. Documentos de trabajo Fundación Carolina, n. 3, 2019. ACOSTA, Diego; BRUMAT, Leiza. Political and Legal Responses to Human Mobility in South America in the Context of the Covid-19 Crisis. More Fuel for the Fire? Frontiers in Human Dynamics, v. 2, n. 20, 2020.

AFP - Agence France Press. Migrantes venezolanos varados en campamento de Bogotá por pandemia. YouTube, 05.06.2020. Available at: <https://www.youtube.com/ watch?v=AbW0vnWn5j8>. Accessed: 09.12.2020.

AGAMBEN, Giorgio. Homo Sacer: Sovereign Power and Bare Life. London: Stanford University Press, 1998.

AGAMBEN, Giorgio. The Omnibus Homo Sacer. London: Stanford University Press, 2017 (2005).

AIROLDI, Massimo. Ethnography and the digital fields of social media. International Journal of Social Research Methodology, v. 21, n. 6, p. 661-673, 2018.

ALCALDIA DE BOGOTA. Estimada concejal, @sarag12. Sobre los venezolanos en el separador de la Autopista Norte, el Distrito les ha ofrecido ayudas como arrendamiento, hospedaje, cuidado y pruebas de COVID-19. Sin embargo, ninguno aceptó las ayudas ni el test de Coronavirus. Twitter, 17.06.2020. Available at: <https://twitter.com/Bogota/status/1273285649651695617>. Accessed: 12.12.2020.

ARENDT, Hanna. The Origins of Totalitarianism. London: Penguin, 2017 (1951).

ARRIBA BOGOTA CITYTV. \#EINoctámbulo visitó el campamento ubicado en la autopista norte con calle 195 en el que se encuentran más de 450 personas que esperan que les autoricen los buses humanitarios hacia la ciudad de Cúcuta para poder llegar a su país natal. Twitter, 03.06.2020. Available at: < https://twitter.com/ ArribaBogota/status/1268180698059493376?s=09>. Accessed: 04.12.2020. 
BETTS, Alexander. Nowhere to go. Foreign Affairs, v. 98, n. 6, p. 122-133, 2019.

BOLÍVAR, Ligia; RODRÍGUEZ, Carlos. Crisis migratoria venezolana y responsabilidad de los Estados. Caracas: Programa venezolano de educación-acción en Derechos Humanos, 2019.

BOLÍVAR, Ligia; RODRÍGUEZ, Carlos. Caminantes de ida y vuelta. El flujo de migrantes venezolanos por el continente en tiempos de pandemia. Caracas: Universidad Católica Andrés Bello, 2021.

BUTLER, Judith. Frames of War. When is life grievable? London: Verso, 2009.

BUTLER, Judith. Precarious Life. London: Verso, 2006.

BUTLER, Judith. Rethinking Vulnerability and Resistance. In: BUTLER, Judith; GAMBETTI, Zeynep; SABSAY, Leticia (eds.). Vulnerability in Resistance. London: Duke University Press, 2016, p. 12-27.

CARACOL RADIO. Drama humanitario de venezolanos en la autopista norte en Bogotá. Facebook Live, 02.06.2020a. Available at: <https://www.youtube.com/ watch?v=xkvROOVKP7o $>$. Accessed: 10.12.2020.

CARACOL RADIO. Venezolanos que vivían en cambuches en la autonorte salieron hacia su país. 04.07.2020b. Available at: < https://caracol.com.co/emisora/2020/07/04/ bogota/1593885002_561027.html>. Accessed: 12.12.2020.

CARDOZO UZCÁTEGUI, Alejandro; MIJARES, Victor. The versatile amalgam: Interests and corruption in Russia-Venezuela relations. European Review of Latin American and Caribbean Studies, n. 109, p. 181-202, 2020.

CDH UCAB - Centro de Derechos Humanos Universidad Católica Andrés Bello. El drama de los retornados: la victimización a la criminalización. Caracas: $\mathrm{CDH}$ UCAB, 2020.

DE HAAS, Hein; CASTLES, Stephen; MILLER, Mark J. The Age of Migration. London: Springer, 2020.

EL ESPECTADOR. "Sólo nos falta una autorización para volver a Venezuela": migrantes en la Autopista Norte. 11.06.2020. Available at: < https://www.elespectador.com/ noticias/bogota/migrantes-en-la-autopista-solo-nos-falta-una-autorizacion-paravolver-a-venezuela/>. Accessed: 04.12.2020.

EL TIEMPO. Migrantes venezolanos resisten en medio de la pandemia. 13.06.2020. Available at: <https://www.youtube.com/watch?v=tigbYl_TsZ0>. Accessed: 10.12.2020.

EL TIEMPO. Colombia cerró el 2020 con un 2,3 \% menos de migrantes venezolanos. 08.02.2021. Available at: <https://www.eltiempo.com/justicia/servicios/cuantosvenezolanos-hay-en-colombia-migracion-presento-balance-de-2020-563859>. Accessed: 28.02.2021.

FASSIN, Didier. La raison humanitaire. Une historie morale du présent. Paris: Seuil/ Gallimard, 2010.

GARCÍA PINZÓN, Viviana; MANTILLA, Jorge. Contested borders: organized crime, governance, and bordering practices in Colombia-Venezuela borderlands. Trends in Organized Crime, 2020. DOI: 10.1007/s12117-020-09399-3. 
GOZZER, Stefania. Coronavirus: el trágico viaje de un grupo de venezolanos que intentó regresar a pie a su país desde Perú en medio de la pandemia. BBC Mundo, 18.05.2020. Available at: <https://www.bbc.com/mundo/noticias-americalatina-52648228>. Accessed: 03.12.2020.

HERMANN, Margaret G. Content Analysis. In: KLOTZ, Audie; PRAKASH, Deepa (eds.). Qualitative Methods in International Relations. London: Palgrave Macmillan, 2008, p. 151-67.

HSIEH, Hsiu-Fang; SHANNON, Sarah. Content Analysis. In: FREY, Bruce (ed.). The SAGE Encyclopedia of Educational Research, Measurement, and Evaluation. Thousand Oaks: Sage, 2018, p. 393-394.

IOM - International Organisation for Migration. Venezuelan Refugee and Migrant Crisis. 2020. Available at: <https://www.iom.int/venezuela-refugee-and-migrant-crisis>. Accessed: 03.02.2021.

KRÜGER, Cristian; RODRÍGUEZ, Ronal; ROBAYO, María Clara; MENDOZA, Laura. Frontera y Movilidad Humana. Bogota: Konrad Adenauer Stiftung, 2020.

MARCUS, George E. Ethnography in/of the World System: The emergence of Multisited Ethnography. Annual Review of Anthropology, v. 24, p. 95-177, 1995.

MÁRQUEZ RESTREPO, Martha Lucía. Relaciones bilaterales entre Colombia y Venezuela ante la crisis y el Posacuerdo. In: PASTRANA BUELVAS, Eduardo; GEHRING, Hubert (eds.). La crisis venezolana impactos y desafíos. Bogota: Konrad Adenauer Stiftung, 2019, p. 493-512.

MAZZA, Jacqueline. Venezuelan Migrants under Covid 19: Managing South America's Pandemic amid a Migration Crisis. Latin American Program, Working Paper. Washington: Woodrow Wilson Centre for Scholars, December 2020.

MEZZADRA, Sandro; NEILSON Brett. The Border as Method, or, the Multiplication of Labour. London: Duke University Press, 2013.

MIGRACIÓN COLOMBIA. Declaraciones de nuestro Director General, Juan Francisco Espinosa Palacios, frente a la situación que se está presentando con los migrantes venezolanos que desean retornar a su país y no lo pueden hacer debido a las restricciones impuestas por Venezuela. Facebook Live. 09.06.2020a. Available at: <https://www.facebook.com/301178233334429/videos/2996741880404336>. Accessed: 12.12.2020.

MIGRACIÓN COLOMBIA. Declaraciones del Director General de Migración Colombia, Juan Francisco Espinosa Palacios, frente al por qué es necesario coordinar los desplazamientos de venezolanos hacia la frontera. Facebook Live. 30.04.2020b. Available at: <https://www.facebook.com/301178233334429/ videos/232631121351236>. Accessed: 12.12.2020.

MIGRACIÓN COLOMBIA. Número de venezolanos radicados desciende por primera vez en cinco años. 28.05.2020c. Available at: <https://www.migracioncolombia. gov.co/noticias/numero-de-venezolanos-radicados-en-colombia-desciende-porprimera-vez-en-5-anos>. Accessed: 01.12.2020.

NOTICENTRO 1. CM\& Emisión Central 09 de junio 2020. Youtube, 09.06.2020. Available at: <https://www.youtube.com/watch?v=OI5yPPh-_NA >. Accessed: 03.12.2020. 
NOTICIAS CARACOL. "Queremos irnos a nuestro país": venezolanos instalaron cambuches en la autopista Norte de Bogotá. YouTube, 22.05.2020a. Available at: $<$ https://www.youtube.com/watch?v=SOwmZOcHZrQ>. Accessed: 09.12.2020.

NOTICIAS CARACOL. Frustrada jornada de salud con grupo de 400 migrantes a quienes se les iba a realizar prueba de coronavirus en el norte de Bogotá. Twitter, 09.06.2020b. Available at: <https://twitter.com/NoticiasCaracol/ status/1270427382361587713>. Accessed: 05.12.2020.

NOTICIAS RCN. Alcaldía dice que venezolanos en cambuches se negaron a tomarse prueba de covid-19. YouTube, 13.06.2020. Available at: < https://www.noticiasrcn. com/bogota/alcaldia-dice-que-venezolanos-en-cambuches-se-negaron-tomarseprueba-de-covid-19-358316>. Accessed: 13.12.2020.

OHCHR - Office of the UN's High Commissioner for Human Rights. Preliminary findings of the visit to the Bolivarian Republic of Venezuela by the Special Rapporteur on the negative impact of unilateral coercive measures on the enjoyment of human rights. 12.02.2021. Available at: <https:/www.ohchr.org/EN/NewsEvents/Pages/ DisplayNews.aspx?NewsID=26747\&LangID=E > . Accessed: 01.03.2021.

ORDOÑEZ, John Thomas; RAMÍREZ ARCOS, Hugo. (Des)orden nacional: la construcción de la migración venezolana como una amenaza de salud y seguridad pública en Colombia. Revista Ciencias de la Salud, v. XVII, p. 48-68, 2019.

PÁEZ, Tomas; VIVAS, Leonardo. The Venezuelan Diaspora. Another Impending Crisis? Freedom House Report, 2017. Available at: <https://www.researchgate.net/ publication/317099053_The_Venezuelan_Diaspora_Another_Impending_Crisis.> Accessed: 02.02.2021.

PALMA-GUTIERREZ, Mauricio. El doble discurso migratorio como estrategia política. La Silla Vacía, 01.12.2020. Available at: < https://lasillavacia.com/silla-Ilena/red-devenezuela/doble-discurso-migratorio-como-estrategia-politica-77397>. Accessed: 01.03.2021.

PALMA-GUTIERREZ, Mauricio. Las razones detrás del estatuto de protección. La Silla Vacía, 10.02.2021a. Available at: < https://lasillavacia.com/silla-llena/redde-venezuela/las-razones-detras-del-estatuto-de-proteccion-77657> . Accessed: 10.02.2021.

PALMA-GUTIERREZ, Mauricio. The Politics of Generosity. Colombian Official Discourse towards Migration from Venezuela, 2015-2018. Colombia Internacional, n. 106, April 2021b. (In press).

R4V - Coordination Platform for Refugees and Migrants from Venezuela. Refugees and Migrants from Venezuela. [dataset] 05.11.2020. Available at: <https://r4v.info/en/ situations/platform>. Accessed: 08.01.2021.

RAMOS PISMATARO, Francesca; RODRÍGUEZ, Ronal. Colombia de cara a los desafíos y oportunidades que representa la Migración venezolana. In: PASTRANA BUELVAS, Eduardo; GEHRING, Hubert (eds.). La Crisis Venezolana. Impactos y Desafíos. Bogotá: Konrad Adenauer Stitftung, 2019, p. 546-77.

RODRÍGUEZ, Ronal; ROBAYO, María Clara. Las migraciones en el contexto colombovenezolano. Bogota: Konrad Adenauer Stiftung and Universidad del Rosario, 2019. 
SCHEEL, Stephan. Autonomy of Migration? Appropriating mobility within biometric border regimes. London: Routledge, 2019.

SCHEEL, Stephan; RATFISCH, Philipp. Refugee Protection Meets Migration Management: UNHCR as a Global Police of Populations. Journal of Ethnic and Migration Studies, v. 40, n. 6, p. 924-941, 2014.

SECRETARÍA DE GOBIERNO. Hoy viajaron a su país los últimos migrantes venezolanos de los 700 que se encontraban en la Autopista Norte. Desde el Distrito se les brindó atención en salud, pruebas Covid, alimentación y albergues a los que aceptaron. Twitter, 29.07.2020. Available at: < https://witter.com/GobiernoBTA/ status/1288261258127577097>. Accessed: 01.12.2020.

SNELSON, Chareen. Qualitative and Mixed Methods Social Media Research: A Review of the Literature. International Journal of Qualitative Methods, v. 15, n. 1, p. 1-15, 2016.

SULBARÁN, Rafael David. Infiltrados de Maduro pagan para que migrantes formen cambuches en las calles. Proyecto Migra Venezuela, 10.06.2020. Available at: $<$ https://migravenezuela.com/web/articulo/gaby-arellano-infiltrados-de-madu ropagan-para-que-migrantes-se-queden-en-las-calles-/1952>. Accessed: 06.12.2020.

TARACIUK BRONER, Tamara. The Venezuelan Walkers. Human Rights Watch, 05.09.2018. Available at: <https:/www.hrw.org/news/2018/09/05/venezuelanwalkers>. Accessed: 28.03.2020.

TAZZIOLI, Martina. The Making of Migration. London: Sage, 2020.

TORRADO, Santiago. La alcaldesa de Bogotá agita el debate sobre la xenofobia contra los venezolanos en plena pandemia. El País, Madrid, 04.04.2020. Available at: $<$ https://elpais.com/internacional/2020-04-03/la-alcaldesa-de-bogota-agita-eldebate-sobre-la-xenofobia-contra-los-venezolanos-en-plena-pandemia.html>. Accessed: 03.12.2020.

TRUJILLO, Carlos Holmes. Declaración inicial del Canciller Holmes Trujillo en la rueda de prensa con el enviado especial de la ONU para la atención de la crisis migratoria proveniente de Venezuela, Eduardo Stein. Ministerio de Relaciones Exteriores (Colombia), 20.08.2019. Available at: < https://www.cancilleria.gov.co/ en/declaracion-inicial-canciller-holmes-trujillo-rueda-prensa-enviado-especialonu-atencion-crisis >. Accessed: 22.11.2020.

UNDERBERG, Natalie; ZORN, Elaine. Digital ethnography anthropology, narrative, and new media. Austin: University of Texas Press, 2013.

UNHCR - United Nations High Commissioner for the Refugees. Se lanza Plan de Emergencia para refugiados y migrantes de Venezuela. Press Release, 14.12.2018. Available at: <https://www.acnur.org/noticias/press/2018/12/5c13bcf14/se-lanzaplan-de-emergencia-para-refugiados-y-migrantes-de-venezuela.html>. Accessed: 10.12.2020.

UNHCR - United Nations High Commissioner for the Refugees. UNHCR and IOM welcome Colombia's decision to regularize Venezuelan refugees and migrants. Press Release, 08.02.2021. Available at: <https://www.unhcr.org/uk/news/ press/2021/2/60214cf74/unhcr-iom-welcome-colombias-decision-regularizevenezuelan-refugees-migrants.html>. Accessed: 01.03.2021. 
WELSH, Teresa. Venezuela crisis is 'on the scale of Syria,' UNHCR says. Devex, 19.09.2018. Available at: <https://www.devex.com/news/venezuela-crisis-is-onthe-scale-of-syria-unhcr-says-93465 > . Accessed: 28.02.2021.

WORLD BANK. Una oportunidad para todos. Los migrantes y refugiados venezolanos en el desarrollo del Perú. Washington: World Bank, 2019. 